\title{
Appeared Problem and Effectiveness of Strategy in Developing Western Provinces
}

\author{
Xue He Lai Ti·Ma He Mu Ti, Zulati Litifu, Ma Chang Fa \\ The Institute of Information and Statistics, Xinjiang University of Finance and Economics \\ Urumqi, Xinjiang, China.830012.xohratm@sina.com, zulati@gmail.com
}

Received: March 18, 2019. Revised: May 15, 2021. Accepted: October 7, 2021. Published: November 24, 2021.

\begin{abstract}
This paper ${ }^{1}$ analyzed and compared the main macroeconomic indicators of Xinjiang Uygur Autonomous Region (XUAR) of China and the other provinces in China, by using the macroeconomic data of China and 12 western provinces from 1999 to 2011 and considering the indicators of average developing level and economic development. Results from this study shows that the main problems existing in the process of economic development include several aspects in XUAR, such as lacking scale of fixed and foreign investment, and existed big gap of people's income between XUAR and the whole country and the other western provinces, and also, the industrial structure is not reasonable. Therefore, XUAR should fully use the golden opportunity for a new round of western development strategy including national policy on counterpart support, and makes effort in improving investment environment and expanding the ways to attract foreign investment as well as increasing the resident's income to reduce the gap in income. Currently, the most urgent task of XUAR is to adjust local industrial structure and speed up the social economy so as to catch up with the average developing level of China.
\end{abstract}

Keywords - XUAR; Western regions; Efficiency analysis; Developing regional economy; suggestions

\section{INTRODUCTION}

$\mathrm{T}_{\mathrm{i}}^{\mathrm{o}}$ O coordinately develop local economy and reduce the gap in economic development between regions of western and eastern in China, the China government decided to implement the western development strategy since1999, and in 2000, the national conference about XUAR's Economic Development is held, on which the counterpart support that come from national 19 provinces and regions was decided for XUAR. This event created a d evelopment opportunities for XUAR's economy. During past period of three years, XUAR has made the significant progress in developing economy, and at the same time, the existing gap in economic development has been reduced. However, it is necessary to know the actual contribution for the XUAR from the national strategic policy of developing the western region including XUAR, and to know the function of the strategic policy in reducing the gap of economic development. This is what all researchers and local government very concerned about. This paper analyzed and compared the main macroeconomic indicators of XUAR and the other provinces under the condition of preferential policies, by using the macroeconomic data of China and 12 western provinces from 1999 to 2011 and considering the situation of average and current value in local economic development. Simultaneously, this paper analyzed the problems in the process of developing local economy to provide reasonable and applicable idea and method for XUAR government so as to perfectly make economic plan and fulfill economic policies.

\section{ACHIEVEMENT IN SOCIAL ECONOMY OF XUAR UNDER POLICY OF DEVELOPING THE WESTERN REGIONS}

\section{A. Achievement in total GDP}

Statistic data shows that the gap between XUAR and 12 western provinces has been reducing day by day since the policy of developing western region was fulfilled, the XUAR's Economy growth has increased by 14.9 percent on an annual basis and the total GDP increased from 116.317 billion Yuan (unit of Chinese money, 1dolar equals to 6.34 Yuan currently) in 1999 to 661.005 billion Yuan in 2011 as shown in Fig. 1.

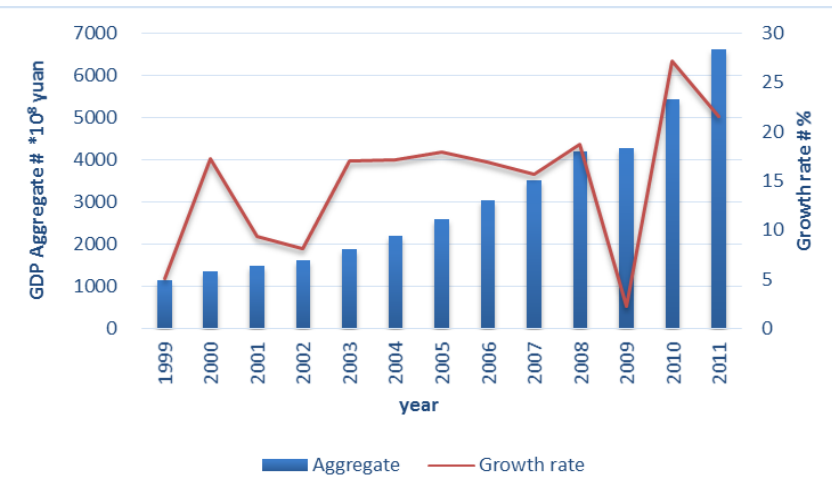

Fig.1.The total GDP and growth speed of XUAR from 1999 to 2011

XUAR's Economic development is not only shown in the increase of the total GDP, and also reflects in the increase of GDP per capita. GDP per capita increased from 6,443 Yuan in 1999 to 30,087 Yuan in 2011, this level not only has passed through the ten thousands Yuan barrier, and 4.67 times more than the value in 1999, the average growth rate reached by 12.59 percent on an annual basis. These indexes indicate that the XUAR's economic aggregate has entered a new stage of development as shown in Fig. 2. 
INTERNATIONAL JOURNAL OF COMPUTERS

DOI: $10.46300 / 9108.2021 .15 .10$

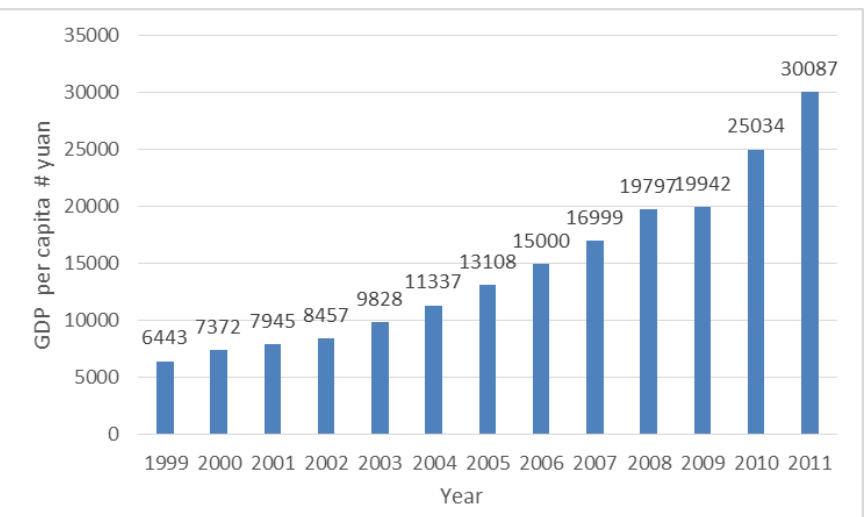

Fig.2.Characteristics of GDP per capita in XUAR from 1999 to 2011

\section{B. Enlarging the Scale of Investment}

Since the policy of developing the western region was implemented, the rapid improve of XUAR's economy is mainly due to enlarged scale of investment that has been continually increasing under the guidance of national policy. Investment scale reached 471.277 billion Yuan up to 2011, which accounts for 1.5 percent of total investment in China, the average growth rate is by 18.2 percent on an annual basis as shown in Fig.3.

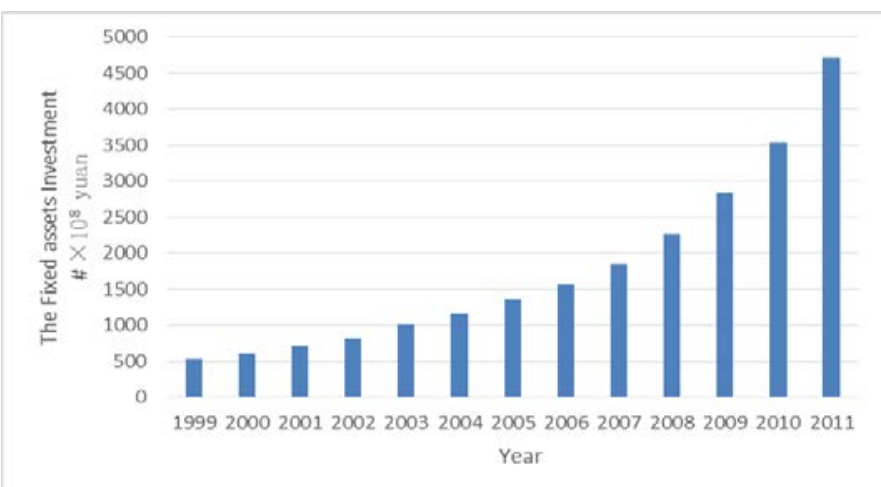

Fig.3.Characteristics of investment in fixed assets in XUAR from 1999 to 2011

\section{Adjusting and Optimizing Three-industry Structure}

In the circumstance of times of large-scale development of the western regions, the industrial structure of XUAR has been adjusted and optimized in according to the needs of social and economic development. Industrial structure shows a decline in the proportion of primary industry and secondary industry shows significantly increased trend. As a result, the proportion and relationship of three-industry structure approach to the level of developing countries. Up to 2011, the proportion of three-industry structure shows the number by 17.2:48.8:33.96. Although the third industry has been rapid development for years, it is still lower than the 2.2 percentage points of GDP growth over the same period.

\section{The improvement of government revenue and people's living standards}

Accompanied by the increment of total economy in XUAR as shown in Fig.4, regional fiscal revenue also greatly improved. As of 2011, the annual fiscal revenue has reached 72.043 billion Yuan, this value shows an increase of 10.1 times compared with 1999 and increased by 19.5 percent on an annual basis, which is the fastest growing speed of XUAR's revenue over the years. Here, Fig.5 and Fig. 6 are respectively indicate the disposable income per capita and its growth of urban residents and Net income per capita of rural residents.

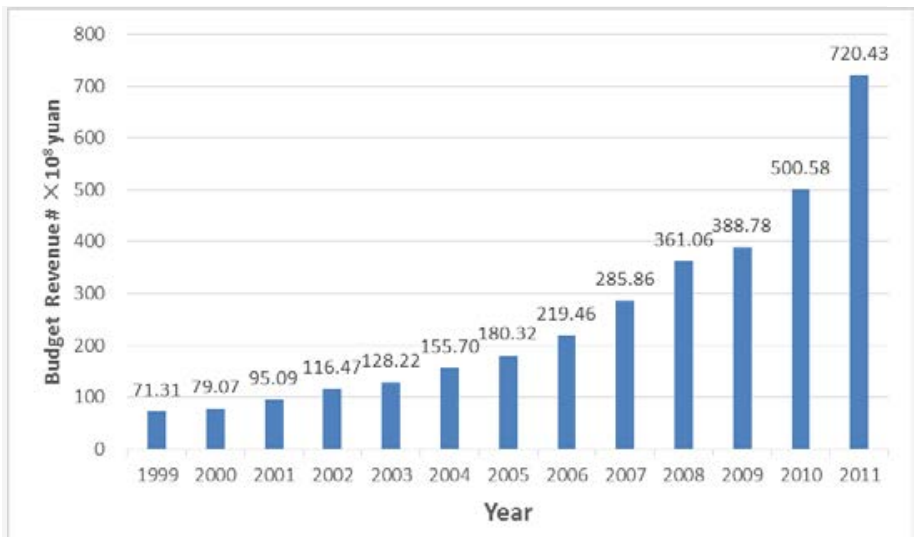

Fig.4. Characteristic curve of XUAR's local revenue from general budget from 1999 to 2011

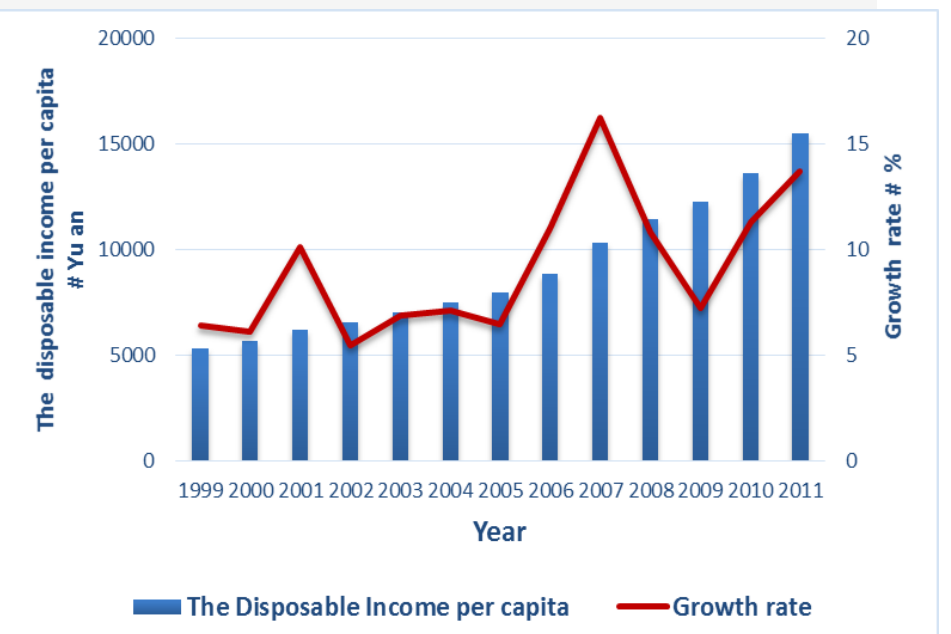

Fig.5. Disposable income per capita and its growth of urban residents in XUAR from 1999 to 2011

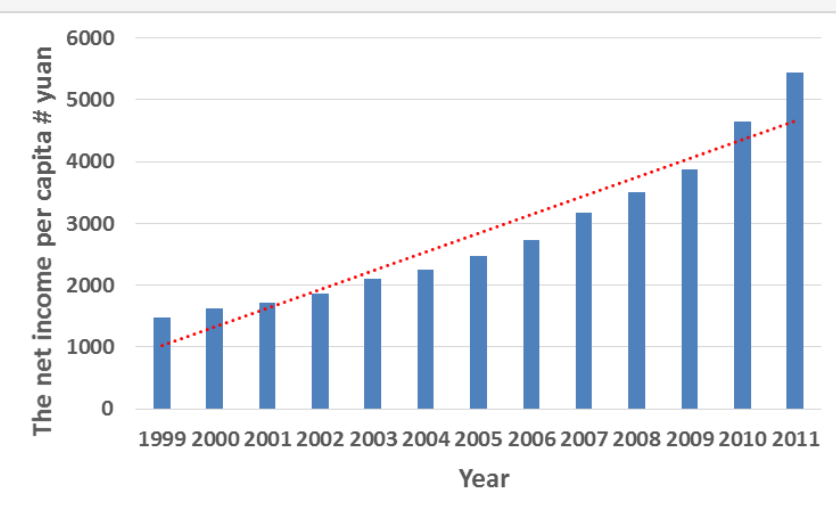

Fig.6. Net income per capita of rural residents in XUAR from 1999 to 2011

The improvement of people's living standard is mainly reflected in the growth of disposable income per capita. As of 2011, disposable income per capita of urban residents and rural residents respectively reached 15,514 Yuan and 5,442 Yuan. The improvement shows a corresponding increment in 
the level of income per capita in urban and rural residents than the level in 1999. In the period to 2011, the growth in income per capita of rural residents is faster than that of rural residents, which is mainly benefited from the preferential policies for agriculture promulgated by the state.

The increment of disposable income per capita has greatly promoted the consumption level of urban and rural residents. Up to 2011, XUAR's total retail sales reached 155.709 billion Yuan with an increase of 4.48 times compared to 1999 and increased by 12.2 percent annually as shown in Fig. 7.

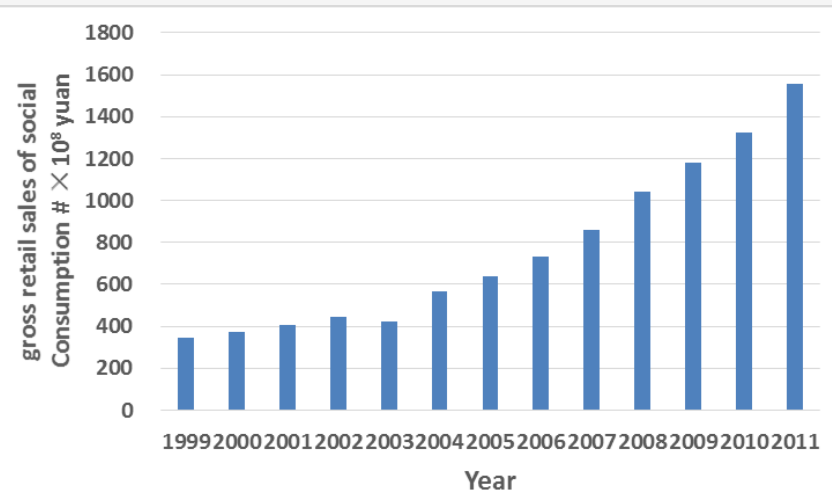

Fig.7. Total retail sales of social consumption in XUAR from 1999 to 2011

\section{E. Significant Progress in Foreign Trade}

In the period of developing the western regions, XUAR government established friendly and cooperative relations with neighboring provinces and cities, and also has established long-term cooperative relationship with the neighboring countries at the same time. As of 2011, the total foreign trade volume reached 22.822 billion U.S. dollars, with an increase of 12.9 times compared to 1999 and an annual growth rate of $21.8 \%$ in average. The main types of foreign trade goods are textiles and leather and tomato sauce as well.

\section{COMPARISON OF ECONOMIC DEVELOPMENT LEVEL OF XUAR AND OTHER WESTERN PROVINCES}

Since the large-scale development of the western region, although socio-economic in XUAR shows rapid development, anyway, the regional developing level is still lower than that of other western provinces. The paper selected nine indicators related to local economic development, by which the economic development condition of XUAR in 13 years were applied and compared with that of other western provinces and regions.

\section{A. Comparison of total GDP and its growth rate}

In 2011, total GDP of XUAR reached 661.005 billion Yuan, which is six-folded the value of 116.32 billion Yuan in 1999 and ranked at the seventh in the western provinces and regions. The total GDP accounts for $6.6 \%$ of the proportion of the western provinces and autonomous regions. GDP growth rate in 2011 reduced to $14.3 \%$ from $16.47 \%$, the percentage before the policy of western development was implemented. Although the ranking of total GDP has not changed in the western provinces and autonomous regions, the growth rate dropped five places in all western provinces as shown in Table 1.
TABLE 1: GDP AND ITS GROWTH RATE OF 12 PROVINCES IN THE WESTERN REGION

\begin{tabular}{|c|c|c|c|c|}
\hline \multirow{3}{*}{$\begin{array}{c}12 \text { provinces } \\
\text { in the } \\
\text { western } \\
\text { China }\end{array}$} & \multicolumn{4}{|c|}{1999} \\
\hline & GDP & \multirow{2}{*}{ Rank } & \multirow{2}{*}{$\begin{array}{l}\text { Growth } \\
\operatorname{rate}(\%)\end{array}$} & \multirow{2}{*}{ Rank } \\
\hline & (10 ${ }^{8}$ Yuan) & & & \\
\hline Xinjiang & 1163.2 & 7 & 16.47 & 5 \\
\hline $\begin{array}{r}\text { Inner } \\
\text { Mongolia }\end{array}$ & 1379.3 & 6 & 16.5 & 4 \\
\hline Tibet & 105.9 & 12 & 15.42 & 6 \\
\hline Gansu & 956.3 & 8 & 14.44 & 9 \\
\hline Qinghai & 239.4 & 11 & 13.34 & 11 \\
\hline Ningxia & 264.6 & 10 & 15.21 & 7 \\
\hline Guizhou & 937.5 & 9 & 13.38 & 10 \\
\hline Yunnan & 1899.8 & 3 & 17.73 & 1 \\
\hline Guangxi & 1971.4 & 2 & 17.03 & 3 \\
\hline Shanxi & 1592.6 & 5 & 15.08 & 8 \\
\hline Sichuan & 3649.1 & 1 & 12.18 & 12 \\
\hline chongqing & 1663.2 & 4 & 17.69 & 2 \\
\hline \multirow{3}{*}{$\begin{array}{c}12 \text { provinces } \\
\text { in the } \\
\text { western } \\
\text { China }\end{array}$} & \multicolumn{4}{|c|}{2011} \\
\hline & GDP & \multirow{2}{*}{ Rank } & \multirow{2}{*}{$\begin{array}{l}\text { Growth } \\
\operatorname{rate}(\%)\end{array}$} & \multirow{2}{*}{ Rank } \\
\hline & (10 $0^{8}$ Yuan) & & & \\
\hline Xinjiang & 6610.05 & 7 & 14.3 & 10 \\
\hline $\begin{array}{r}\text { Inner } \\
\text { Mongolia } \\
\end{array}$ & 14359.88 & 2 & 19.75 & 1 \\
\hline Tibet & 605.83 & 12 & 14.36 & 9 \\
\hline Gansu & 5020.37 & 9 & 13.6 & 11 \\
\hline Qinghai & 1670.44 & 11 & 16.12 & 4 \\
\hline Ningxia & 2102.21 & 10 & 17.28 & 2 \\
\hline Guizhou & 5701.84 & 8 & 14.9 & 5 \\
\hline Yunnan & 8893.12 & 6 & 12.61 & 12 \\
\hline Guangxi & 11720.87 & 4 & 14.7 & 7 \\
\hline Shanxi & 12512.3 & 3 & 17.18 & 3 \\
\hline Sichuan & 21026.68 & 1 & 14.42 & 8 \\
\hline chongqing & 10011.37 & 5 & 14.81 & 6 \\
\hline
\end{tabular}

\section{B. Investment in Fixed Assets}

The scale of investment in fixed assets declined in XUAR in 2011, investment value decreased from 6 in 1999 to seven in 2011. The proportion of investment accounted respectively for $9.4 \%$ in 1999 and $6.42 \%$ in 2011 of all western provinces, Sichuan Province ranked first in this index in 2011 as shown in Table 2.

TABLE 2: INVESTMENT IN FIXED ASSETS OF 12 WESTERN PROVINCES AND AUTONOMOUS REGIONS

\begin{tabular}{|c|c|c|c|c|}
\hline \multirow{2}{*}{$\begin{array}{c}12 \\
\text { provinces } \\
\text { in the } \\
\begin{array}{c}\text { western } \\
\text { China }\end{array}\end{array}$} & $\begin{array}{c}\text { Total } \\
\text { Investment } \\
\left(10^{8} \text { yuan }\right)\end{array}$ & Rank & $\begin{array}{c}\text { Total } \\
\text { Investment } \\
\left(10^{8} \text { yuan }\right)\end{array}$ & Rank \\
\cline { 2 - 5 } Xinjiang & 534.65 & 6 & 4632.14 & 7 \\
\hline
\end{tabular}




\begin{tabular}{|c|c|c|c|c|}
$\begin{array}{c}\text { Inner } \\
\text { Mongolia }\end{array}$ & 383.37 & 8 & 10365.17 & 2 \\
\hline Tibet & 50.75 & 12 & 516.31 & 12 \\
\hline Gansu & 384.08 & 7 & 3965.79 & 9 \\
\hline Qinghai & 128.13 & 11 & 1435.58 & 11 \\
\hline Ningxia & 130.61 & 10 & 1644.74 & 10 \\
\hline Guizhou & 333.9 & 9 & 4235.92 & 8 \\
\hline Yunnan & 717.28 & 2 & 6191 & 6 \\
\hline Guangxi & 620.2 & 3 & 7990.66 & 4 \\
\hline Shanxi & 619.27 & 4 & 9431.08 & 3 \\
\hline Sichuan & 1220.66 & 1 & 14222.22 & 1 \\
\hline Chongqing & 562.87 & 5 & 7473.38 & 5 \\
\hline
\end{tabular}

\section{The structure of three-industry}

The proportion of three-industry structure from the primary industry in order is $17.23: 48.80: 33.97$. the primary and tertiary industry respectively decreased by5.87 and 6.83 percentage points compared with 1999, but the secondary industry increased by 12.7 percentage points. In 2011, comparing with average proportion accounted by primary and tertiary industry in all western provinces and nation, the average proportion of XUAR promoted very fast with the growth rate by $4.49 \%$ of primary and by $7.19 \%$ of tertiary industry. Simultaneously, the proportion of secondary industry respectively declined and increased, which shows a decrease of 2.12 percentage points comparing with the level of all western provinces and an increase of 2.19 percentage points comparing with the level of nation. At the same time, the proportion of tertiary industry also declined respectively by 2.37 and 9.38 percentage points as shown in Table 3.

TABLE 3: THE STRUCTURE OF THREE-INDUSTRY OF 12 WESTERN PROVINCES IN 2009 AND 2011

\begin{tabular}{|c|c|ccc|}
\hline names & 1999 & \multicolumn{3}{|c|}{2011} \\
\hline $\begin{array}{c}\text { the national } \\
\text { average }\end{array}$ & $15.6: 54.4: 30.0$ & $10.0:$ & 46.6 & 43.4 \\
\hline $\begin{array}{c}\text { the western } \\
\text { region's average }\end{array}$ & $23.0: 38.8: 38.2$ & $12.7:$ & 50.9 & 36.3 \\
\hline Xinjiang & $23.1: 36.1: 40.8$ & $17.2:$ & $48.8:$ & 34.0 \\
Inner Mongolia & $24.9: 37.0: 38.1$ & $9.1:$ & $55.9:$ & 34.9 \\
Tibet & $32.3: 22.5: 45.2$ & $12.2:$ & $34.4:$ & 53.2 \\
Gansu & $20.1: 42.8: 37.1$ & $13.5:$ & $47.3:$ & 39.1 \\
Qinghai & $17.6: 39.3: 47.1$ & $9.2:$ & $58.3:$ & 32.3 \\
Ningxia & $18.2: 39.2: 42.6$ & $8.7:$ & $50.2:$ & 41.0 \\
Guizhou & $28.6: 37.3: 34.1$ & $12.7:$ & $38.4:$ & 48.8 \\
Yunnan & $21.4: 42.7: 35.9$ & $15.8:$ & $42.5:$ & 41.6 \\
Guangxi & $28.8: 34.6: 36.6$ & $17.4:$ & $48.4:$ & 34.1
\end{tabular}

\begin{tabular}{|c|c|c|c|c|}
\hline Shanxi & $16.0: 42.8: 41.2$ & 9.7: & 55.4: & 34.8 \\
\hline Sichuan & $25.4: 37.0: 37.6$ & 14.1: & 52.4: & 33.4 \\
\hline Chongqing & $17.2: 42.0: 40.8$ & 8.4: & 55.3: & 36.2 \\
\hline
\end{tabular}

\section{Industrial added value}

During the large-scale development of the western regions, XUAR has achieved rapid development, the industrial added value reached 270.02 billion Yuan in 2011 and ranks 7 of the 12 western provinces and autonomous regions, the ranking is 6 in 1999. The proportion of industrial added value of XUAR accounted for $6.29 \%$ of 12 western provinces and autonomous regions in 1999 , however, that value dropped to $6.26 \%$ in 2011 as shown in Table 4.

TABLE 4: THE INDUSTRIAL ADDED VALUE OF 12 WESTERN PROVINCES AND AUTONOMOUS REGIONS

\begin{tabular}{|c|c|c|c|c|}
\hline \multirow{2}{*}{$\begin{array}{c}12 \\
\text { provinces } \\
\text { in the } \\
\text { western } \\
\text { region }\end{array}$} & \multicolumn{2}{|c|}{1999} & \multicolumn{2}{c|}{2011} \\
\cline { 2 - 4 } & Industrial & \multirow{2}{*}{ added value } & Rank & \multicolumn{2}{|c|}{$\begin{array}{c}\text { Industrial } \\
\left(10^{8} \text { Yuan }\right)\end{array}$} & & $\begin{array}{c}\text { added value } \\
\left(10^{8} \text { Yuan }\right)\end{array}$ & Rank \\
\hline Xinjiang & 317.93 & 8 & 2700.2 & 7 \\
Inner & 428.33 & 6 & 7101.6 & 2 \\
Mongolia & 9.97 & 12 & 48.18 & 12 \\
Tibet & 327.68 & 7 & 1923.95 & 8 \\
Gansu & 69.96 & 11 & 811.73 & 11 \\
Qinghai & 80.7 & 10 & 816.79 & 10 \\
Ningxia & 284.16 & 9 & 1829.2 & 9 \\
Guizhou & 680.01 & 2 & 2994.3 & 6 \\
Yunnan & 579.26 & 3 & 4851.37 & 4 \\
Guangxi & 487.26 & 5 & 5857.92 & 3 \\
Shanxi & 1293.53 & 1 & 9491.05 & 1 \\
Sichuan & 492.39 & 4 & 4690.46 & 5 \\
Chongqing & & & & \\
\hline
\end{tabular}

\section{E. GDP per capita}

Compared with other provinces in the west area, GDP per capita of XUAR was in the middle and upper levels in 2011 and ranked 5 in all western provinces, however, XUAR ranked No.1 in 1999. Inner Mongolia ranked No.1 in 2011 as shown in Table 5.

TABLE 5: GDP PER CAPITA OF 12 WESTERN PROVINCES AND

\begin{tabular}{|c|c|c|c|c|}
\hline $\begin{array}{c}12 \\
\text { provinces } \\
\text { in the } \\
\text { western } \\
\text { provinces }\end{array}$ & $\begin{array}{c}|c| \\
\text { GDP per } \\
\text { capita } \\
\text { (yuan) }\end{array}$ & Rank & $\begin{array}{c}\text { GDP per } \\
\text { capita (yuan) }\end{array}$ & Rank \\
\cline { 2 - 5 } Xinjiang & 6443 & 1 & 30087 & 5 \\
$\begin{array}{c}\text { Inner } \\
\text { Mongolia }\end{array}$ & 5861 & 2 & 57974 & 1 \\
Tibet & 4180 & 9 & 20077 & 9 \\
Gansu & 3778 & 11 & 19595 & 10
\end{tabular}




\begin{tabular}{|c|c|c|c|c|} 
Qinghai & 4728 & 5 & 29522 & 6 \\
Ningxia & 4900 & 4 & 33043 & 4 \\
Guizhou & 2545 & 12 & 16413 & 12 \\
Yunnan & 4558 & 6 & 19265 & 11 \\
Guangxi & 4444 & 7 & 25326 & 8 \\
Shanxi & 4415 & 8 & 33464 & 3 \\
Sichuan & 4540 & 5 & 26133 & 7 \\
Chongqing & 5413 & 3 & 34500 & 2 \\
\hline
\end{tabular}

F. Total retail sales of social consumer goods

Total retail sales of social consumer goods of XUAR decreased from ranking 7 to 9 from 1999 to 2011 , reducing the two ranking position. The proportion of total retail sales of social consumer goods of XUAR accounted for $6.4 \%$ of the western provinces and autonomous regions in 1999, the value of proportion fell to $4.99 \%$ in 2011. Sichuan Province is No.1 in total retail sales of social consumer goods in 2011 as shown in Table 6.

TABLE 6: TOTAL RETAIL SALES OF SOCIAL CONSUMER GOODS IN 12 WESTERN PROVINCES AND AUTONOMOUS REGIONS.।

\begin{tabular}{|r|c|c|c|c|}
\hline \multirow{2}{*}{$\begin{array}{c}\text { 12 provinces } \\
\text { in the western } \\
\text { provinces }\end{array}$} & $\begin{array}{c}\text { Gross retail } \\
\text { sales of social } \\
\text { consumption } \\
\left(10^{8} \text { yuan }\right)\end{array}$ & Rank & $\begin{array}{c}\text { c } \\
\text { Gross retail } \\
\text { sales of social } \\
\text { consumption } \\
\left(10^{8} \text { yuan }\right)\end{array}$ & Rank \\
\hline $\begin{array}{r}\text { Xinjiang } \\
\text { Inner }\end{array}$ & 347.41 & 7 & 1616.30 & 9 \\
Mongolia & 532.60 & 6 & 3991.70 & 2 \\
Tibet & 37.63 & 12 & 219.00 & 12 \\
Gansu & 346.99 & 8 & 1648.00 & 8 \\
Ninghai & 91.79 & 10 & 410.50 & 11 \\
Guizhou & 82.71 & 11 & 477.60 & 10 \\
Yunnan & 313.79 & 9 & 1751.60 & 7 \\
Guangxi & 538.95 & 1 & 3000.10 & 6 \\
Shanxi & 791.27 & 3 & 3908.20 & 3 \\
Sichuan & 657.80 & 5 & 3790.00 & 4 \\
Chongqing & 667.01 & 4 & 3487.80 & 5 \\
\hline
\end{tabular}

\section{G. Import and export}

The total volume of import and export has been greatly improved, but the rank declined from 3 in 1999 to 4 in 2011. The proportion of the total import and export volume accounted averagely for $12.4 \%$ of the western provinces and autonomous regions in 1999 and 2011. XUAR's foreign trade showed good condition and achieved the rapid development as shown in Table 7.

TABLE 7: COMPARISON OF IMPORT AND EXPORT VOLUME OF 12 WESTERN PROVINCES AND AUTONOMOUS REGIONS

\begin{tabular}{|l|l|l|}
\hline 12 & 1999 & 2011 \\
\hline
\end{tabular}

\begin{tabular}{|r|c|c|c|c|}
\hline $\begin{array}{r}\text { provinces in } \\
\text { the western } \\
\text { provinces }\end{array}$ & $\begin{array}{c}\text { Import and } \\
\text { export trade } \\
\left(10^{8} \mathrm{US}\right. \\
\text { dollars })\end{array}$ & Rank & $\begin{array}{c}\text { Import and } \\
\text { export trade } \\
\left(10^{8} \mathrm{US}\right. \\
\text { dollars })\end{array}$ & Rank \\
\hline Xinjiang & 17.6534 & 3 & 228.19672 & 4 \\
$\begin{array}{r}\text { Inner } \\
\text { Mongolia }\end{array}$ & 16.0786 & 6 & 119.30904 & 7 \\
Tibet & 1.6622 & 11 & 13.58369 & 11 \\
Gansu & 5.6953 & 8 & 87.28579 & 8 \\
Qinghai & 1.0784 & 12 & 9.23818 & 12 \\
Ningxia & 3.1799 & 10 & 22.85747 & 10 \\
Guizhou & 5.4763 & 9 & 48.87579 & 9 \\
Yunnan & 16.5967 & 5 & 160.28773 & 5 \\
Guangxi & 17.5322 & 4 & 233.55966 & 3 \\
Shanxi & 20.0834 & 2 & 146.4727 & 6 \\
Sichuan & 24.7069 & 1 & 477.24169 & 1 \\
Chongqing & 12.1044 & 7 & 292.07635 & 2 \\
\hline
\end{tabular}

\section{H. Net income per capita of farmers and herdsmen}

The net income per capita of XUAR's farmers and herdsmen is 5,442 Yuan in 2011, an increment of three-fold based on 1,473 Yuan in 1999. In 2011, the net income per capita of XUAR's farmers and herdsmen shown the growth of 10.5 percent, which is 1.3 and 1 percentage points higher than that of nation (is $10.5 \%$ ) and the western provinces (is 9.5\%). In ranking net income per capita of farmers and herdsmen in 2011, XUAR ranks fourth in the country, Inner Mongolia Autonomous Region obtained the first position in rank.

\section{General budget revenue}

The general budget revenue of XUAR in 2011 is 72.043 billion Yuan, the ranking rose from 9 in 1999 to 8 in 2011, accounted proportion in all western provinces rose from $6.2 \%$ in 1999 t o $6.7 \%$ in 2011. Sichuan and Shaanxi Province respectively obtained the highest proportion of the first and second.

\section{Problems EXISTING IN DEVELoPING XUAR ECONOMY DURING DEVELOPMENT OF THE WESTERN REGIONS}

\section{A. Lack of investment scale in Fixed assets and foreign}

Although the total scale of XUAR's investment is continually expanding and the cumulative amount of investment is also increasing, the accounted proportion of fixed asset investment in the country and the western provinces shows a downward trend. In 2011, XUAR's investment in fixed assets is 471.277 billion Yuan that is eight times of that in 1999 and accounts for the proportion of $1.45 \%$ of country's total investment, this value is 0.3 percentage points lower than that in 1999. In 1999, XUAR's investment in fixed assets accounted for the proportion of $9.4 \%$ in the western provinces and ranked 7 in order. But in 2011, the investment in fixed assets of XUAR decreased by an order in rank in the western provinces and accounted proportion dropped to $6.2 \%$. On the other hand, the 
utilization of foreign capital has dropped due to lacking the way to attract foreign investment. As a result in 2011, XUAR utilized foreign direct investment of 13.796 billion Yuan that dropped down to $0.26 \%$ from $1.76 \%$ of the proportion of total investment in 1999.

\section{B. Big gap in income of urban residents and lacking multiple ways in fiscal revenue}

Income of urban residents in XUAR is relatively simple and mainly dependent on wage. In 2011, wage income accounted for $71.8 \%$ of total household income, which is respectively higher than 7.5 percentage points of the national average level and 4.1 percentage points of the of western province's average level. Disposable income per capita of XUAR's urban residents is relative lower than that of the country and the 12 western provinces and autonomous regions. In 2011, disposable income per capita of urban residents was 15,514 Yuan that was 5,320 Yuan more than that in 1999 increasing by three times, anyway, which is lower than the national per capita income level of 6,296 Yuan, and also, 2,645 Yuan lower than that of the western provinces and autonomous regions. Of urban residents per capita disposable income growth is lower than 12 provinces and autonomous regions of the country and western, the average annual growth rate of $8.58 \%$ of the per capita disposable income of urban residents in Xinjiang from 1999 to 2011, the growth rate was $13.7 \%$, compared with the national average growth rate of 0.4 percentage points lower than the 1.2 percentage points compared with the western provinces.

\section{Irrational industrial structure demanding further optimized}

Being low in Industrial level and irrational in industrial structure, in 2011, the proportion of three industrial structure is 17.23:48.80:33.97 in order. Comparing with national proportion of 10.04:46.61:43.35, regional primary and tertiary industry respectively accounted for a larger and lower proportion. The proportion of the population engaged in agriculture in Xinjiang is higher than the national average level, and regional agricultural is with low level in science and technology. The internal hierarchical of Xinjiang agricultural shows that the structure of primary industry is relatively sole, which is dominated by farming and agriculture accounted for a large proportion, but forestry and animal husbandry as well as fishery accounted for the low proportion.

The internal structure of Xinjiang regional industry indicated that the proportion of heavy industry is big and light industry is small, the development rate of light and heavy industry is under disproportion. Since the founding of New China, the foundation of Xinjiang light industry and agriculture is weak, therefore, the state has established a number of heavy chemical enterprises, especially the enterprises of raw materials and energy industries, which form the industrial structure that contains more proportion of heavy industry ${ }^{[1]}$.

Now, regional industry is generally small-scaled enterprises, which accouters for a high proportion in general enterprises, and weak in competitiveness. In 2011, proportion of tertiary industry is respectively 9.38 and 2.37 percentage points lower than that of average level of national and the western provinces in comparison. The regional tertiary industry is dominated by transport, postal services, wholesale and retail trade, but the education, technology, culture, computer services and tourism as well as other service industries is not enough in tertiary industry.

\section{Suggestions to Accelerate AND DeVelop Social ECONOMY IN XUAR}

\section{A. Improving the investment environment and increasing Fixed Investment and strengthening the capacity of attracting foreign investment}

Xinjiang's economy should iincrease the proportion of investment in fixed assets and improve the investment structure and the efficiency of investment, so as to further develop the support role of investment in boosting and developing social economy. To increasing the degree of state investment, especially the investment degree for state-owned enterprises, regional government should maintain and promote the steady growth of state-owned investment.

On the other hand, to increase investment scale of the livelihood and improve the projects of public infrastructure, regional economy should shows function in continuously improving the people's living standards. To seize the opportunities of national policy to support their counterparts in Xinjiang, the establishment of economic and trade cooperation with the mainland provinces and autonomous regions is necessary under this policy environment, widening the channels to attract foreign investment and its scale. Improving the infrastructural construction, provide the convenient transportation for domestic and foreign investors, and improve the network services so as to build a comfortable environment for investment and strengthen attraction of foreign investment.

\section{B. Improvement of the Growth in the Income of Urban Residents}

For now, the main source of income of urban residents depends on their wage in Xinjiang. To achieve the rapid growth of income of urban residents, the faster growth rate of wage must be ensured. This paper argues that from the following two aspects to accelerate the growth rate of per capita income, thus speeding up the rapid improvement of Xinjiang's total GDP. First, it is necessary to adjust the income distribution. From the viewpoint of wage income constitutes, the income of Xinjiang's enterprises is less compared with other western provinces and autonomous regions, the main source of income structure is the wage of organs and institutions. Therefore, in order to constantly improved income distribution system of organs and institutions, establishment of normal growth mechanism is important for guaranteeing payment of the employee's salary ${ }^{[2]}$. On this basis, it is necessary to timely adjust the allowances of the organs and institutions and continually improve the wage adjusting and monitoring mechanism, thereby narrowing the gap with the national and the other western provinces and autonomous regions. Second, actively broaden the income sources of residents. On the one hand, the government should encourage and guide enterprises to continuously improve the level of wages of workers to lay the foundation for the steady growth 
of income of urban residents. On the other hand, government preferential policies should encourage individuals and businesses to develop their own businesses and actively carry out investment and diversified economy. By these ways, operating income from multi-channel of the residents may be effectively improved so that residents have more income from property.

\section{Adjustment of the industrial structure}

Adjusting the proportion of three industries and optimizing industrial structure is the basis to play a leading role in industry. Now, Xinjiang Region is in the initial stage of industrialization, therefore, it is important, in the three industries, to make the secondary industry bigger and stronger, and vigorously develop the tertiary industry at the same time so that to increase the proportion of tertiary industry. State and Government should encourage farmers and lead the peasants to improve the level of scientific farming, quality of farmers and reduce agricultural population, and make it possible to transfer the rural labor to the industrial and service sectors.

As a whole situation, Xinjiang region is in the early stage of industrialization. Lacking of capital and high-quality talent, the resource's advantage could not duly play. Therefore, in view of the reverse movement of production factors among different regions, the Xinjiang Region should increase the industry to take advantage of the superior resources of the region, rather than arranging production by the relative comparative advantage $^{[3]}$.

For the second industry, it is necessary to expand the scale of industrial enterprises in order to attract more foreign investment and increase the construction of large industrial enterprises. For the tertiary industry, is necessary to rely on Xinjiang's unique natural and cultural resources, vigorously develop the tourism industry in Xinjiang. On the other hand, Xinjiang's government should catch the opportunity of the central work conference to construct Urumqi and Kashi Cities into an international trade center and financial center ${ }^{[4]}$. By taking advantages of location and the preferential policies of the state and optimizing the structure of three industries, it is possible to speed up the development in economy and society in Xinjiang Region.

\section{CONCLUSION}

In This paper, the main macroeconomic indexes of Xinjiang Uygur Autonomous Region (XUAR) is analyzed based on the actual data related to the regional economy; and the analyzed results are compared with the condition of Chinese national and the other provinces in western region of China. The results from this paper indicates the problems in developing economy of western provinces, especially economic condition of Xinjiang Uygru Autonomous region considering the special geographic location, population and resources that occupies large proportion in entire China. The indicated problems in this paper are very important in practice for a long time due to many existing situation that can not change by the effort of the provinces located in the western region of China. Now, many of inner provinces that are the strongest in economics are involved in the support action of western provinces, such support action shows very big efficiency in developing local economy and increasing the job position for native residents. The results from this paper may taken as the reference in future works, and this result may be applied for the province not only in western provinces but also can be used for other province in China, where the local economic is currently under development.

\section{REFERENCES}

[1] Fei Chang-hong,Yang Zhi-yong,“An Analysis on the Situation of Development of Economy and Society in Xinjiang Region Since Reforming and Opening"Journal of Analysis on Xinjiang History, 2009(2), pp110-117.

[2] Adili Nur, "Current Situation and Problems and Countermeasures of the Income of Urban Residents in Xinjiang”[J]. Chinese and foreign entrepreneurs, 2012(4) : 7476.

[3] Liu Chunyun, "Current Situation and Countermeasures of Xinjiang's economic development" [J]. Cooperation in economy and technology, 2010 (15) : pp9-10.

[4] Gao Zhong Lun, Mujiang Long. "Thinking of the national counterpart support economic and social development in Xinjiang”[J]. Contemporary economy, 2011 (1) : pp88-89.

\section{Creative Commons Attribution License 4.0 (Attribution 4.0 International, CC BY 4.0)}

This article is published under the terms of the Creative Commons Attribution License 4.0

https://creativecommons.org/licenses/by/4.0/deed.en_US 